Gi respons på artikler gjennom artiklenes kommentarfelt på tidsskriftet.no.

Innleggene publiseres fortløpende på Tidsskriftets nettside og et utvalg

av innleggene publiseres også i papirutgaven i spalten «Brev til redaktøren».

Redaksjonen forbeholder seg retten til å foreta redaksjonelle endringer.

Forfattere av vitenskapelige artikler har tilsvarsrett, jf. Vancouver-gruppens regler.

\section{Re: Spesialpoliklinikk for skjelettdysplasier}

$\mathrm{K}$. Rosendahl og medarbeidere orienterer om sitt tilbud om spesialpoliklinikk for skjelettdysplasier ved Haukeland universitetssykehus i Tidsskriftet nr. 5/2015 (1). På vegne av Skjelettdysplasiteamet ved Oslo universitetssykehus vil vi opplyse om at Oslo Universitetssykehus også har en Skjelettdysplasiklinikk. Hos oss møter pasienten/familien barneendokrinolog, barneortoped, fysioterapeut, fagperson fra Trenings- og rådgivningssenteret og klinisk genetiker i en tverrfaglig konsultasjon. Røntgenbilder gjennomgås av radiologer med ekspertise innen skjelett/muskel- og barneradiologi. Etter konsultasjonen forfatter vi en felles rapport med forslag til oppfølgning og behandling som kan foregå både lokalt og sentralt. Noe av oppfølgningen kan dessuten skje ved Skjelettdysplasiklinikken når dette er indisert.

$\mathrm{Vi}$ har egen klinikk for pasienter med osteogenesis imperfecta. Fra 2016 har vår ortopediske avdeling nasjonalt behandlingsansvar for medfødte deformiteter i underekstremiteter hos barn, noe som kommer barn med achondro- og hypochondroplasi til gode.

Vi kan motta pasienter fra hele landet, men mener det ofte er hensiktsmessig at henvisning skjer til skjelettdysplasiklinikk i egen helseregion når tilbudet finnes.

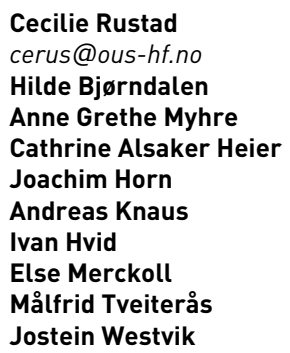

Forfatterne er overleger som inngår i Skjelettdysplasiteamet ved Oslo universitetssykehus.

Ingen oppgitte interessekonflikter.

\section{Litteratur}

1. Rosendahl K, Houge G, Gradek GA et al. Spesialpoliklinikk for skjelettdysplasier. Tidsskr Nor Legeforen 2015; 135: 419-20.

\section{Re: En mann i 60-årene som uventet og dramatisk forsøker selvmord}

Marianne Holms gjennomgang av behandling og forløp hos en mann med psykotisk depresjon i Tidsskriftet nr. 4/2015 (1) er et godt eksempel på kvalitetskontroll, der problemstillingen er: «Ble det riktige gjort, og ble det gjort riktig?» (2). Først etter cirka ett år kom de første små tegn til bedring - en uke etter påbegynt litium monoterapi. Sakte, men sikkert bedret pasienten seg ytterligere. Holm konkluderer med at litium burde vært forsøkt tidligere. Jeg er enig.

Dessverre er litium som antidepressivum kommet i skyggen av andre midler, fordi større og nyere studier ikke er gjort. Men syv små dobbeltblinde randomiserte, kontrollerte studier fra 1970-80årene viste minst like god effekt av litium monoterapi som trisykliske antidepressiva (TCA), og bedre effekt enn placebo (3). Enda bedre dokumentert er den forsterkende effekten litium kan ha på antidepressiver $(3,4)$. Derfor mener jeg litium skulle ha vært forsøkt sammen med et antidepressivum. Da kunne bedringen ha kommet raskere.
Holm spør seg om årsaken til forverringen første året kan ha skyldtes for lave doser eller for kort behandlingstid med antidepressiver. Men bare doseringen av sertralin er oppgitt, 50-100 mg. Dette ble brukt i kombinasjon med en «forsiktig dose» olanzapin. Tre dobbeltblinde randomiserte, kontrollerte studier av nyere medikamenter har vist bedre effekt på psykotisk depresjon av et antidepressivt og antipsykotisk medikament sammen enn hver av dem alene (5). Kombinasjonene var sertralin pluss olanzapin, venlafaksin pluss kvetiapin og fluoksetin pluss olanzapin. Gjennomsnittlig dosering var sertralin $170 \mathrm{mg}$, venlafaksin $373 \mathrm{mg}$, fluoksetin $23 \mathrm{mg}$, olanzapin $12-15 \mathrm{mg}$ og kvetiapin $599 \mathrm{mg}$. Det ville være interessant å vite hvor langt fra disse dosene Holms pasient var når det gjelder olanzapin og venlafaksin. Klomipramindosen er også interessant, da dette preparatet ofte må doseres høyt.

Holm nevner at man i ettertid så at energimengden ved elektrostimulerende behandling (ECT) ikke var optimal. Det ville derfor være av interesse å få vite energimengden og hvilke(n) elektrodeplassering som ble brukt.

Jeg tror at konklusjonen i denne kvalitetskontrollen er at optimal behandling ble startet for sent, doseringen av antidepressiva, antipsykotika og ECT var suboptimal, litium ble ikke brukt som potensering av antidepressiva, men bare som monoterapi, og for sent i forløpet.

\section{Per Bergsholm \\ per.bergsholm@gmail.com}

Per Bergsholm (f. 1945) er overlege ved Akuttpsykiatrisk seksjon, Klinikk psykisk helse og avhengighet, Oslo universitetssykehus. Ingen oppgitte interessekonflikter.

Litteratur

1. Holm M. En mann i 60-årene som uventet og dramatisk forsøker selvmord. Tidsskr Nor Lægeforen 2015; 135: 338-40.

2. Wyszewianski L. Quality of care: past achievements and future challenges. Inquiry 1988; 25: 13-22.

3. Bschor T. Lithium in the treatment of major depressive disorder. Drugs 2014; 74: 855-62.

4. Bauer M, Adli M, Bschor T et al. Lithium's emerging role in the treatment of refractory major depressive episodes: augmentation of antidepressants. Neuropsychobiology 2010; 62: 36-42.

5. Rothschild AJ. Challenges in the treatment of major depressive disorder with psychotic features. Schizophr Bull 2013; 39: 787-96.

\section{Holm svarer:}

Som Bergsholm påpeker, og som jeg skrev i artikkelen, burde litium vært forsøkt langt tidligere. Med den dramatiske starten på oppholdet, som pasient og pårørende tilskrev antidepressiver, ble imidlertid introduksjon av nye psykofarmaka generelt vanskelig.

Min kliniske erfaring er at litium fortjener en betydelig større plass enn den har ved vanskelig behandlbare, alvorlige depresjoner med eller uten psykotiske symptomer og selvmordstanker.

På grunn av taushetsplikten kan jeg dessverre ikke komme med ytterligere detaljer rundt psykofarmakadoser og elektrostimulerende behandling.

\section{Marianne Holm}

marianne.holm@sthf.no

Marianne Holm (f. 1959) er overlege ved Alderspsykiatrisk avdeling,

Psykiatrisk klinikk, Sykehuset Telemark.

Ingen oppgitte interessekonflikter. 